\title{
UJI NEUROLOGICAL DEPRESSION DISORDERS INVENTORY FOR EPILEPSY (NDDI-E) PADA PASIEN EPILEPSI DI POLIKLINIK SARAF RSUP PROF. DR. R. D. KANDOU
}

\author{
${ }^{1}$ Joshua Lengkoan \\ ${ }^{2}$ Herlyani Khosama \\ ${ }^{2}$ Maja Sampoerno
}

\author{
${ }^{1}$ Kandidat Skripsi Fakultas Kedokteran Universitas Sam Ratulangi Manado \\ ${ }^{2}$ BagianNeurologi Fakultas Kedokteran Universitas Sam Ratulangi Manado \\ Email: j.lengkoan_11_142@yahoo.co.id
}

\begin{abstract}
Depression is a comorbid symptom that often occurs in epileptic patients. This study aimed to obtain the occurence of depression among epileptic patients at the Neurology Department Prof. Dr. R. D. Kandou Hospital Manado. This study used a cross-sectional design for diagnostic test. Respondents were all patients that came to the Neurology clinic at Neurology Department Prof. Dr. R. D. Kandou Hospital Manado. There were 30 epileptic cases during the period of October to November 2014 that fulfilled the inclusion and exclusion criteria. Based on the outcome of questionnaires distributed to respondents and the manual calculation with standardized score of Neurological Depression Disorders Inventory for Epilepsy (NDDI-E) >15, diagnosis of depression was confirmed. There were 10 depression cases among the 30 respondents. Conclusion: Neurological Depression Disorders Inventory for Epilepsy Indonesian Version could be used to detect depression disorders among epileptic patients.
\end{abstract}

Keyword: epilepsy, depression, NDDI-E

\begin{abstract}
Abstrak: Depresi adalah salah satu gejala komorbid yang sering terjadi pada pasien epilepsi. Penelitian ini bertujuan untuk mengetahui gambaran depresi pada pasien epilepsi di Poliklinik Saraf RSUP Prof. Dr. R. D. Kandou Manado. Penelitian dilakukan menggunakan desain potong lintang untuk uji diagnostik dengan mengambil sampel semua pasien epilepsi yang datang ke Poliklinik Saraf BLU RSU Prof. Dr. R. D. Kandou Manado. Terdapat 30 pasien epilepsi yang berobat ke poliklinik saraf RSUP Prof. Dr. R. D. Kandou Manado bulan Oktober sampai November 2014 yang memenuhi kriteria inklusi dan ekslusi. Dari hasil kuesioner yang dibagikan kepada responden dan melalui hasil perhitungan manual dengan standar skor Neurological Depression Disorders Inventory for Epilepsy (NDDI-E) $>15$ diagnosis mengalami depresi ditetapkan. Hasil penelitian menunjukkan 10 dari 30 responden mengalami depresi. Simpulan: Neurological Depression Disorders Inventory for Epilepsy (NDDI-E) versi Bahasa Indonesia dapat digunakan dalam mendeteksi gangguan depresi pada pasien epilepsi.
\end{abstract}

Kata kunci: epilepsi, depresi, NDDI-E

Depresi adalah salah satu gejala komorbid yang sering terjadi pada pasien epilepsi. Terjadinya gejala depresi pada pasien epilepsi merupakan ekspresi dari beberapa mekanisme patogenik: perubahan neurokimia dan neurofisiologis yang terjadi dalam struktur limbik dalam perjalanan epilepto, proses iatrogenik (sifat psikotropika negatif obat antiepilepsi, bedah epilepsi), dan proses reaktif terhadap gangguan kronis dan faktor risiko genetik. Prevalensi depresi pada pasien epilepsi 
diperkirakan antara 9-62\%. Komorbiditas depresi pada epilepsi memengaruhi secara negatif pada kualitas hidup, meningkatkan risiko bunuh diri, dan biaya perawatan medis bila dibandingkan dengan pasien tanpa inhibitor depresi selektif serotonin reuptake serotonin selective dan norepinephrin reuptake inhibitor serta pengobatan lini pertama depresi pada pasien epilepsi. ${ }^{1}$

Epilepsi adalah salah satu penyakit neurologi tertua dan ditemukan pada semua umur. Menurut WHO (2012) diperkirakan terdapat sekitar 50 juta orang dengan epilepsi di dunia. Populasi epilepsi aktif (penderita dengan bangkitan tidak terkontrol atau yang memerlukan pengobatan) diperkirakan antara 4 hingga 10 per 1000 penduduk per tahun, dan di negara berkembang diperkirakan 6 hingga 10 per 1000 penduduk. $^{2}$

Di Indonesia belum ada data yang pasti mengenai penderita epilepsi, tetapi diperkirakan terdapat 1-2 juta penderita epilepsi. Prevalensi epilepsi di Indonesia 510 kasus per 1.000 orang dan insiden 50 kasus per 100.000 orang per tahun. ${ }^{3}$ Dari hasil penelitian yang dilakukan di poliklinik saraf Prof. Dr. R. D. Kandou Manado periode 1 Januari sampai 31 Desember 2011 didapatkan bahwa penderita baru rawat jalan epilepsi berjumlah $0,51 \%$ dari seluruh penderita penyakit saraf rawat jalan. ${ }^{4}$ Sampai saat ini belum ada data dasar tentang depresi pada penderita epilepsi di Manado.

Salah satu cara untuk mendeteksi depresi pada epilepsi yaitu dengan menggunakan instrumen Neurological Depression Disorders Inventory for Epilepsy (NDDI-E) yang telah di validasi. Meskipun NDDI-E tidak dapat menggantikan evaluasi definitif, pemeriksaan ini dapat membantu mendeteksi dini depresi pada pasien epilepsi di poli rawat jalan. $^{5}$

\section{METODE PENELITIAN}

Penelitian ini dilakukan menggunakan desain potong lintang untuk uji diagnostik.
Penelitian ini dilakukan di Poliklinik Saraf BLU RSU Prof. Dr. R. D. Kandou Manado pada bulan Oktober sampai November 2014.

\section{HASIL DAN BAHASAN}

Telah dilakukan penelitian terhadap 30 pasien epilepsi yang berobat ke poliklinik saraf RSUP Prof. Dr. R. D. Kandou Manado bulan Oktober sampai November 2014 yang telah memenuhi kriteria inklusi dan ekslusi. Dari hasil kuesioner yang dibagikan kepada responden dan melalui hasil perhitungan manual dengan standar skor NDDI-E >15 dapat ditentukan adanya depresi. Terdapat 10 dari 30 responden yang mengalami depresi (Tabel 1).

Epilepsi adalah suatu gangguan yang berhubungan dengan sistem saraf pusat, yang ditandai dengan adanya bangkitan kejang yang disebabkan oleh hiperaktifitas muatan listrik dari neuron otak secara spontan. ${ }^{6}$ Depresi adalah suatu perasaan kesedihan yang psikopatologis dimana depresi dapat merupakan suatu gejala (sindroma) dan dapat pula sebagai suatu kesatuan penyakit nosologik. $^{7}$

Depresi pada epilepsi merupakan dua gangguan yang mempunyai dampak morbiditas dan mortalitas pada penderita dari masing-masing gangguan tersebut. Hal yang tidak menguntungkan ialah kedua gangguan tersebut dapat terjadi pada satu pasien dan kondisi ini disebut dengan komorbiditas. Hal tersebut tidak hanya meningkatkan masalah morbiditas dan mortalitas saja tetapi menimbulkan masalah baru seperti semakin rumitnya penanganan masalah tersebut. ${ }^{8}$

Gangguan depresi merupakan kelainan yang sering terjadi pada pasien epilepsi. Hal ini merupakan kondisi komorbid yang dapat menurunkan kualitas hidup dan berpotensi menyebabkan timbulnya kebiasaan bunuh diri pada pasien epilepsi. ${ }^{9}$

Depresi merupakan gangguan mood. Hal ini lebih sering terjadi pada orang dengan epilepsi daripada yang tanpa epilepsi atau kondisi neurologis lainnya. ${ }^{10}$ 
Jurnal e-Clinic (eCl), Volume 3, Nomor 2, Mei-Agustus 2015

Tabel 1. Hasil pengisian kuesioner responden penelitian

PERNYATAAN

\begin{tabular}{|c|c|c|c|c|c|c|c|}
\hline Nama & $\begin{array}{c}\text { Semua persoalan } \\
\text { sukar diatasi }\end{array}$ & $\begin{array}{l}\text { Tidak satupun yang } \\
\text { kukerjakan benar }\end{array}$ & Merasa bersalah & $\begin{array}{c}\begin{array}{c}\text { Lebih baik saya } \\
\text { mati }\end{array} \\
\end{array}$ & Frustasi & $\begin{array}{c}\begin{array}{c}\text { Sulit menemukan } \\
\text { kesenangan }\end{array} \\
\end{array}$ & Total \\
\hline MK & 4 & 3 & 3 & 1 & 3 & 2 & 16 \\
\hline AT & 2 & 2 & 3 & 1 & 3 & 2 & 13 \\
\hline AP & 4 & 2 & 3 & 1 & 1 & 2 & 13 \\
\hline OK & 2 & 2 & 2 & 1 & 1 & 1 & 9 \\
\hline NM & 4 & 3 & 2 & 1 & 3 & 4 & 17 \\
\hline FK & 3 & 3 & 3 & 3 & 1 & 3 & 15 \\
\hline JK & 3 & 1 & 1 & 2 & 2 & 2 & 11 \\
\hline AP & 4 & 3 & 3 & 2 & 2 & 3 & 17 \\
\hline JL & 1 & 3 & 1 & 1 & 2 & 4 & 12 \\
\hline OR & 3 & 1 & 1 & 1 & 3 & 4 & 13 \\
\hline MP & 2 & 3 & 3 & 1 & 2 & 3 & 13 \\
\hline $\mathrm{JD}$ & 3 & 3 & 3 & 2 & 2 & 1 & 14 \\
\hline TP & 4 & 3 & 4 & 1 & 3 & 2 & 17 \\
\hline JS & 3 & 2 & 3 & 1 & 2 & 2 & 14 \\
\hline SB & 2 & 2 & 1 & 1 & 1 & 2 & 9 \\
\hline $\mathrm{JK}$ & 2 & 3 & 3 & 1 & 1 & 3 & 13 \\
\hline ES & 4 & 4 & 1 & 4 & 4 & 3 & 20 \\
\hline ME & 3 & 2 & 3 & 2 & 3 & 2 & 15 \\
\hline ET & 4 & 3 & 4 & 1 & 3 & 4 & 19 \\
\hline $\mathrm{ZN}$ & 4 & 2 & 4 & 2 & 3 & 4 & 19 \\
\hline MK & 3 & 1 & 3 & 1 & 4 & 1 & 13 \\
\hline $\mathrm{JT}$ & 3 & 4 & 4 & 4 & 3 & 3 & 21 \\
\hline JS & 3 & 1 & 3 & 1 & 3 & 2 & 13 \\
\hline DR & 4 & 1 & 1 & 1 & 1 & 1 & 9 \\
\hline YK & 2 & 2 & 2 & 3 & 3 & 3 & 15 \\
\hline JS & 1 & 3 & 2 & 2 & 1 & 1 & 10 \\
\hline SM & 4 & 2 & 4 & 1 & 3 & 4 & 18 \\
\hline JK & 3 & 2 & 2 & 2 & 2 & 2 & 13 \\
\hline SM & 1 & 1 & 1 & 1 & 1 & 3 & 8 \\
\hline PA & 3 & 2 & 4 & 2 & 2 & 3 & 16 \\
\hline
\end{tabular}

Saat ini, penilaian gangguan depresi bukan pemeriksaan rutin pada klinik-klinik neurologi, dan fakta yang ada juga membuktikan bahwa sebagian pasien dengan gangguan depresi yang tidak terdeteksi secara dini sehingga akhirnya tidak terobati. Hal ini dikarenakan deteksi depresi pada pasien epilepsi cukup sulit dilakukan di poli rawat jalan mengingat waktu yang diperlukan cukup lama. Oleh karena itu diperlukan pemeriksaan yang singkat dan sederhana namun bisa diandalkan untuk mendeteksi gangguan depresi pada pasien epilepsi.

Penelitian ini dilakukan di Manado untuk melihat frekuensi dan gambaran pada setiap pernyataan yang dapat menjadi acuan dalam meneliti depresi pada pasien epilepsi. $^{9}$ Deteksi depresi meningkat hampir 10 kali lipat dengan menggunakan instrumen NDDI-E ini. Meskipun NDDI-E tidak untuk menggan-tikan evaluasi definitif, pemeriksaan ini dapat membantu mendeteksi dini depresi pada pasien epilepsi di poli rawat jalan. ${ }^{9}$

Pada penelitian ini dalam kurun waktu
2 bulan didapatkan 30 penderita epilepsi yang berobat rawat jalan di poliklinik RSUP Prof. Dr. R. D. Kandou Manado yang memenuhi kriteria inklusi. Berdasarkan pemeriksaan dengan menggunakan kuesioner NDDI-E didapatkan 10 orang yang mengalami depresi, terdiri dari 8 orang perempuan (80\%) dan 2 orang lakilaki (20\%). Hal ini sesuai dengan beberapa penelitian sebelumnya yang juga menyatakan bahwa gangguan depresi mayor pada pasien epilepsi lebih tinggi pada perempuan (71\%). Demikian pula penelitian Daniela Di Capua (2012) di Spanyol mendapatkan pasien epilepsi $72 \%$ pada perempuan, Todokoro (2012) di Jepang 58,3\%, dan De oliveira (2010) di Brazil 70\%.

Pada penelitian ini, umur pasien epilepsi yang mengalami depresi berkisar 16-53 tahun, sedangkan yang tidak mengalami depresi berkisar 17-46 tahun.

Pada kategori status pekerjaan, dari 10 orang pasien yang mengalami depresi terdapat 8 orang yang tidak memiliki pekerjaan, dan 2 di antaranaya berstatus swasta dan mahasiswa. 


\section{SIMPULAN}

1. Neurological Depression Disorders Inventory for Epilepsy (NDDI-E) versi Bahasa Indonesia bisa digunakan untuk mendeteksi gangguan depresi pada pasien epilepsi dengan hasil yang signifikan.

2. NDDI-E versi Indonesia dapat mendeteksi gangguan depresi pada pasien epilepsi pada titik potong $>15$.

\section{SARAN}

1. Pemeriksaan ini kiranya dapat digunakan dalam dunia medis khususnya di Manado untuk mendeteksi gangguan depresi dini pada pasien epilepsi.

2. Karena penelitian ini masih sangat terbatas di Indonesia alangkah baiknya tenaga medis dapat menggunakan acuan ini dalam dunia medis sehari-hari jika mendapati pasien epilepsi.

3. Diperlukan penelitian lanjutan untuk mengetahui mengapa gejala depresi pada epilepsi lebih banyak ditemui pada perempuan dibandingkan laki-laki.

\section{DAFTAR PUSTAKA}

1. Bosak M, Dudek D, Siwek M. Depression in Patients with Epilepsy. 2012 Sep [cited: 2014 Sep 23]. Available from: http: //eresources.pnri.go.id/library.php?id=100 00\&key=depression+for+epilepsy.

2. WHO. Epilepsy. WHO fact sheet October 2012; number 999 [cited: 2014 Oct 5]. Available from: http://www.who.int/mediacentre/factsh eets/fs999/en/.

3. Harsono. Buku ajar neurologi klinis. Yogyakarta: Gajah Mada University Press, 2008; p. 119-33.

4. Rumbiak ALE. Gambaran penderita epilepsi pada orang dewasa di poliklinik saraf BLU Prof Dr.R. D Kandou Manado periode 1 Januari 2011 sampai 31 Desember 2011 (Skripsi). Manado: Universitas Sam Ratulangi, 2012.

5. Friedman DE, Kung HD, Laowattana S, Kass JS, Hrachovy RA, Levin HS. Identifying depression in epilepsy in a busy clinical setting enchanced with systemic screening. Seizure. 2009;18(6):429-33.

6. Cockerel OC, Shorvon OD. Epilepsy current concepts: London: Current Medical Literature, 1996.

7. Kaplan HI, Benjamin JS, Grebb JA. Sypnosis of Psychiatry, Behavioural Science Clinical Psychiatry (7th ed.). William \& Wilkins, 1998; p. 539-52, 568-71.

8. Barry JJ, Huynh N, Lenibke A. Depression in Individual with epilepsy. Curr Treat Option Neurol. 2000;2(6):571-85.

9. Rahmi I, Budikayanti A, Lastri DN, et al. Uji Validitas dan Reabilitas Neurological Depression Disorders Inventory for Epilepsy (NDDI-E) Versi Indonesia. Neurona. 2013;31(1):36-40.

10. Devinsky O. Depression \& Epilepsy. 2002 Feb. [cited: 2014 Sep 23]. Available from: http: //eresources.pnri.go.id:2056/docview/236 123345?pq-origsite $=$ summon . 